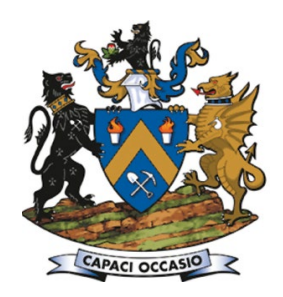

Affiliation:

${ }^{1}$ CSIRO Mineral Resources,

Clayton South, Australia.

Correspondence to:

M.I. Pownceby

Email:

Mark.Pownceby@csiro.au

Dates:

Received: 15 Aug. 2019

Revised: 21 Nov. 2019

Accepted: 29 Nov. 2019

Published: February 2020

How to cite:

Pownceby, M.I., Bruckard, W.J., and Sparrow, G.J.

Technological developments in processing Australian mineral sand deposits.

The Southern African Insitute of Mining and Metallurgy

DOI ID:

http://dx.doi.org/10.17159/24119717/881/2020

This paper was first presented at The Eleventh International Heavy Minerals Conference, 5-6 August 2019, The Vineyard, Cape Town, South Africa.

\section{Technological developments in processing Australian mineral sand deposits}

\author{
M.I. Pownceby ${ }^{1}$, W.J. Bruckard ${ }^{1}$, and G.J. Sparrow ${ }^{1}$
}

\section{Synopsis}

Almost all Australian mineral sand deposits are placer deposits, with the major commercial deposits located in four provinces along the east, west, and south coasts and in ancient basins in the southeast of the country. The development of new technology for mineral separation and its adaption to changes in the mineralogy of the deposits are discussed. Also, a summary is given of novel processing conditions developed to lower the levels of impurity elements (in particular manganese and radionuclides) in the heavy minerals, and to remove gangue minerals to obtain the maximum value from the deposits. The extensive, but still undeveloped, fine-grained Murray Basin deposits will require unique flotation conditions and roasting processes to produce marketable heavy mineral concentrates. The numerous potential novel processes that have been proposed for these deposits are discussed.

\section{Keywords}

mineral sands, mineral processing, technological developments, Australia.

\section{Introduction}

Australia is a major world producer of titanium and zirconium minerals from mineral sand deposits. The principal heavy minerals of commercial value recovered from these deposits are ilmenite $\left(\mathrm{FeTiO}_{3}\right)$, rutile $\left(\mathrm{TiO}_{2}\right)$, and zircon $\left(\mathrm{ZrSiO}_{4}\right)$. According to Geoscience Australia, Australia has the world's largest economic resources of rutile and zircon, and the second largest share of the world's ilmenite resources after China (Britt et al., 2019). Commercial concentrations of titanium and zirconium minerals are found around the world in hard rock deposits, or in placer (alluvial) deposits resulting from the weathering of a hard rock deposit and the concentration of the heavy minerals by wave action on modern or ancient beaches, or by deposition in fluvial (river) systems. Almost all Australian mineral sand deposits are placer deposits, but although alluvial mineral sands occur in many places, commercial concentrations are found in only a small number of locations. The major commercial deposits in Australia are found along the east and west coasts and in ancient basins in the south (Eucla Basin) and southeast (Murray Basin) of the country.

In addition to ilmenite, and its alteration products (including pseudorutile, hydroxylian pseudorutile, and leucoxene, as discussed below), rutile, and zircon, there are usually small amounts of anatase $\left(\mathrm{TiO}_{2}\right)$, monazite ([Ce,La,Th] $\left.\mathrm{PO}_{4}\right)$, xenotime $\left(\mathrm{YPO}_{4}\right)$, cassiterite $\left(\mathrm{SnO}_{2}\right)$, and other lower-value heavy minerals also present in the deposits (Popp, 2005). Major gangue minerals in Australian deposits that can affect processing conditions are aluminium silicates, in particular clay minerals, and oxides such as spinels (e.g., chromite, $\mathrm{FeCr}_{2} \mathrm{O}_{4}$ ). Gangue minerals can form significant proportions (>20\%) of the heavy mineral assemblage and the specific mineral suite can vary significantly.

While ilmenite has a nominal chemical formula of $\mathrm{FeTiO}_{3}\left(\mathrm{FeO}^{-\mathrm{TiO}_{2}}\right)$, assaying $52.7 \mathrm{wt} \% \mathrm{TiO}_{2}$ and $47.3 \mathrm{wt} \% \mathrm{FeO}\left(52.6 \mathrm{wt} \% \mathrm{Fe}_{2} \mathrm{O}_{3}\right)$, this ideal composition seldom occurs in nature due to substitution of impurity elements (e.g., $\mathrm{Mg}, \mathrm{Mn}, \mathrm{V}, \mathrm{Nb}, \mathrm{Fe}^{3+}$ ) for $\mathrm{Fe}^{2+}$ in the crystal lattice, the presence of $\mathrm{Fe}^{3+}$ in $\mathrm{Fe}_{2} \mathrm{O}_{3}$ in solid solution in ilmenite, and incorporation of elements such as $\mathrm{Al}, \mathrm{Si}, \mathrm{U}, \mathrm{Th}, \mathrm{P}$ and $\mathrm{Cr}$ in the pores of grains during weathering of the ilmenite. Weathering is also associated with removal of iron and an increase in $\mathrm{TiO}_{2}$ levels. As a result, in a commercial mineral concentrate, the individual titaniumcontaining grains may have a range of compositions.

> Primary or unaltered ilmenite contains $48-55 \mathrm{wt} \% \mathrm{TiO}_{2}$ with a composition close to the theoretical formula and a $\mathrm{Ti} /[\mathrm{Ti}+\mathrm{Fe}]$ ratio of 0.5 . It may contain some $\mathrm{Fe}^{3+}$ as a haematite-ilmenite solid solution $\left(\mathrm{Fe}_{2} \mathrm{O}_{3}-\mathrm{FeTiO}_{3}\right)$ or as exsolution lamellae of ilmenite-haematite, and appreciable amounts of impurities give rise to the formula $\mathrm{Fe}^{3+}{ }_{2-2 x}\left(\mathrm{Fe}^{2+}, \mathrm{Mg}, \mathrm{Mn}\right)_{\mathrm{x}} \mathrm{Ti}_{\mathrm{x}} \mathrm{O}_{3}$. 


\section{Technological developments in processing Australian mineral sand deposits}

> Secondary or weathered ilmenite has $55-65 \mathrm{wt} \% \mathrm{TiO}_{2}$ and a Ti/[Ti+Fe] ratio between 0.5 and 0.6 . It has a variable composition consisting of a mixture of ilmenite and pseudorutile.

> Pseudorutile is formed on further weathering and has a composition of $60-71 \mathrm{wt} \% \mathrm{TiO}_{2}$ and a Ti/[Ti+Fe] ratio of $0.6-0.7$. This is an iron titanium oxyhydroxide solid solution with one end-member close to $\mathrm{Fe}^{3+}{ }_{2} \mathrm{Ti}_{3} \mathrm{O}_{9}$ and an extended range of homogeneity towards $\mathrm{Fe}^{3+}{ }_{1.5} \mathrm{Ti}_{3} \mathrm{O}_{7.5}(\mathrm{OH})_{1.5}$ (Grey and Reid, 1975).

> Hydroxylian pseudorutile, with a composition of around $70 \mathrm{wt} \% \mathrm{TiO}_{2}$ and a Ti/[Ti+Fe] ratio of $0.85-0.9$, is a porous hydrated iron titanate that can contain more than $10 \mathrm{wt} \%$ water. This mineral is present in the Murray Basin deposits. It has recently been accepted as a new mineral by the International Mineralogical Association and has been given the name kleberite (Grey and Li, 2003; Grey, Steinike, and MacRae 2013).

> Leucoxene is an inhomogeneous, cryptocrystalline, high$\mathrm{TiO}_{2}\left(>70 \mathrm{wt} \% \mathrm{TiO}_{2}\right)$ product of ilmenite weathering with a $\mathrm{Ti} /[\mathrm{Ti}+\mathrm{Fe}]$ ratio of $0.7-0.9$. Further weathering can proceed to form microcrystalline phases similar in composition to rutile.

> Rutile (and its low-temperature polymorph, anatase) is a titanate mineral that usually contains over $95 \mathrm{wt} \% \mathrm{TiO}_{2}$. In natural systems $\mathrm{V}, \mathrm{Fe}, \mathrm{Cr}, \mathrm{Sn}, \mathrm{Mo}, \mathrm{Mn}, \mathrm{Bi}, \mathrm{Nb}$, Ta, and $\mathrm{Sb}$ may substitute into the rutile lattice (Bramdeo and Dunlevey, 1999).

As a result of the wide range of heavy minerals with similar physical properties, and the variable compositions and particle sizes of some, the concentration and separation of the minerals of value in alluvial mineral sand deposits is often not totally efficient and the final mineral products usually contain small amounts of gangue minerals (e.g., quartz and aluminium silicate minerals). A commercial ilmenite concentrate may contain $45-65 \mathrm{wt} \% \mathrm{TiO}_{2}$, the value depending on the composition of the individual mineral ilmenite grains.

Most of the heavy minerals in Australian mineral sand deposits are coarse-grained, such as in the deposits in Western Australia, where the ilmenite has a particle size of nominally 90-300 $\mu \mathrm{m}$. In the Murray Basin deposits, the mineralization is generally finer with deposits in the north of the basin containing ilmenite with a particle size in the range $75-180 \mu \mathrm{m}$, while the further south in the basin that the deposits are located, the finer the particle size of the mineralization. There are major heavy mineral resources in the southeast of the Murray Basin that contain very fine-grained WIM-type mineralization with a particle size of 40-80 $\mu \mathrm{m}$ (Pownceby, 2010).

In this paper the properties of the Australian heavy mineral deposits are discussed, along with the development and advances made in equipment used to produce individual heavy mineral concentrates. Processing conditions developed and modified to treat the changing impurities in these deposits are reviewed.

\section{Australian mineral sand deposits}

Areas in Australia containing the major commercial deposits of mineral sands are shown in Figure 1. Mining of these alluvial mineral sand deposits is done either dry, with earthmoving equipment to excavate and transport the sand, or wet, using dredging techniques when the ground conditions are suitable and access to water is not a problem. The heavy minerals in the mined sand are processed by gravity separation processes or flotation to yield a heavy mineral concentrate (HMC), and then the valuable minerals are separated in a mineral separation plant (MSP) into individual mineral concentrates using a combination of gravity, magnetic, and electrostatic separations or flotation. The commercial development of the Australian mineral sand provinces is discussed in chronological order here.

\section{East coast deposits}

Sediments weathered and eroded from the Lachlan fold belt of eastern Australia were captured by high-energy fluvial systems and transported to the east, where they were deposited to form the eastern Australian heavy mineral deposits along the coast of New South Wales and Queensland. Morley (1981) has presented a detailed review of the people and companies involved in the development and processing of these east coast deposits and the following summary is taken from his publication.

Concentrations of heavy minerals were identified along the east coast of Australia in the 1870s but these 'sniggers' were initially mined for their gold, tin, and platinum content. The first commercial production of zircon, rutile, and ilmenite commenced in 1934 at Byron Bay and expanded to various sites along the New South Wales and Queensland coastlines such that in the 1950s there were up to 33 operations in production. Production from eastern Australia reached its peak in the 1970s but has since decreased and only the mining operations on North Stradbroke Island by Sibelco Australia remain. These are the longest continuously operating sand mining operations in Queensland, but are expected to cease production before 2025 (fact sheet by Wort in Rankin, 2013). Final separation of the minerals is done at the MSP at Pinkenba on the mainland near Brisbane.

The first three companies to commercially produce heavy minerals from the beach sands were Zircon-Rutile Ltd, Metal Recoveries Ltd, and the Titanium Alloy Manufacturing Company. Dry mining with shovels and scoops was used to collect the black beach sand and the heavy minerals were initially recovered as a mixed zircon-rutile-ilmenite concentrate by passing the sand over sluice boxes lined with carpet material and using tables. ZirconRutile Ltd discovered (accidentally) that when the beach sand was added to hot water in the presence of kerosene and soap, on stirring the heavy minerals floated to the surface. Today this 'hot

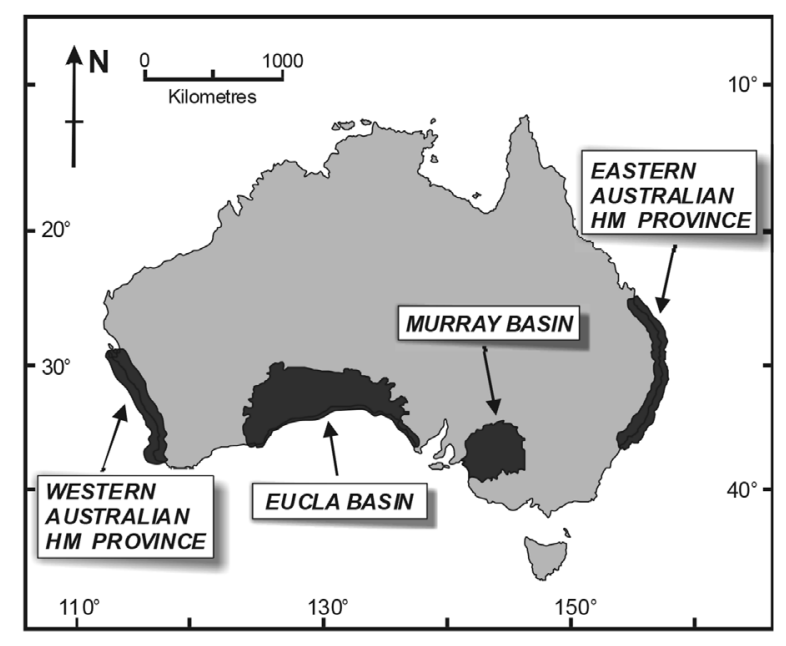

Figure 1-Location of the major mineral sand provinces in Australia (modified from Pownceby, Sparrow, and Fisher-White, 2008) 


\section{Technological developments in processing Australian mineral sand deposits}

soap' flotation process is used to recover many oxide minerals. Moreover, it also was found that the addition of sulphuric acid to the heavy mineral concentrate depressed the rutile and ilmenite, leaving a froth of white zircon. Using this technology, ZirconRutile Ltd focused on producing a zircon concentrate (96-98\% zircon) and a rutile-ilmenite mixture from the beaches around Byron Bay.

After 1945, mining of the sand was carried out with bulldozers and front-end loaders. A dragline was used to strip overburden and a bucket wheel excavator was used to mine hard indurated deposits. Later, when areas were re-worked, the lower grades resulted in the introduction of the floating dredgeconcentrator arrangement. Gravity concentration was with pinched sluices and trays, spirals, and cones. The introduction of magnetic and electrostatic separators allowed the production of individual zircon, rutile, and ilmenite concentrates rather than a combined concentrate.

Mineral Deposits Pty Ltd (now Mineral Technologies, based at Carrara south of Brisbane) was formed at this time, and became a major developer and supplier of gravity, magnetic, and electrostatic separation equipment, and a construction company for the mineral sand industry. Early equipment developed by the company included the Reichert spiral and cone concentrators and electrostatic separators. Also during the same period, H.T. Readings at Lismore commenced the development and manufacturing of electromagnetic separators. Readings is now part of Mineral Technologies.

In the 1930s, the Commonwealth Council for Scientific and Industrial Research (CSIR) established an Ore Dressing Section at Melbourne University. This group worked with the fledgling mineral sands industry to assist in improving processing conditions and the development of downstream products. This government-industry collaboration has continued to the present day through the Commonwealth Scientific and Industrial Research Organisation (CSIRO), with research scientists located at several laboratories around the country.

While the zircon and rutile separated from the east coast deposits were easily marketed, the ilmenite was not suited to the production of white titania pigment by either the sulphate or chloride process due to its high chromium content. It was usually stockpiled or buried. However, with an increased demand for rutile as a feedstock for the new chloride process, Murphyores Inc. Pty Ltd, working with CSIRO from 1963 to 1977, developed the Murso process to upgrade ilmenite (and lower its chromium content) to a synthetic rutile that was a suitable feedstock for the chloride process. The ilmenite was oxidized in air at $1000^{\circ} \mathrm{C}$ to convert $\mathrm{Fe}^{2+}$ to $\mathrm{Fe}^{3+}$ and form micro-cracks in the ilmenite grains. The oxidized product was then reduced at $850-900^{\circ} \mathrm{C}$ in a reducing gas mixture of $\mathrm{H}_{2}-\mathrm{CO}-\mathrm{CO}_{2}-\mathrm{H}_{2} \mathrm{O}$ under conditions that minimized the formation of metallic iron. The highly reactive reduced product was dissolved in $20 \% \mathrm{HCl}$ at $105-110^{\circ} \mathrm{C}$ under reflux and from the acid a high-grade synthetic rutile product containing $96 \mathrm{wt} \% \mathrm{TiO}_{2}$ precipitated. Although a pilot plant was run successfully in Japan, the process was never implemented in practice (Sinha, 1973).

In 1985, in response to a shortfall in world ilmenite production, Consolidated Rutile commenced upgrading stockpiled high-chrome ilmenite at its Pinkenba (Brisbane) MSP using dry magnetic separation to produce a product with a minimum of $50 \mathrm{wt} \% \mathrm{TiO}_{2}$ and a maximum of $0.40 \mathrm{wt} \% \mathrm{Cr}_{2} \mathrm{O}_{3}$ for pigment production (Woodcock and Hamilton, 1993).
The Goondicum mine in central Queensland, owned by Melior Resources Inc. (Melior), is a weathered residual hardrock deposit. Material in the Goondicum crater is mined, crushed, screened and sized, and gravity (spirals) and magnetic separations are used to produce primary ilmenite and apatite concentrates.

\section{West coast deposits}

Mineral sand deposits, many of a commercial size, have been formed by wave action along the coast of Western Australia in the Swan Coastal Plain, which stretches over $600 \mathrm{~km}$ from Jangardup south of Perth to Eneabba in the north. Many of these mineral-bearing strandlines are now located as much as $50 \mathrm{~km}$ inland from the current coastline. The degree of weathering of ilmenite in Western Australian deposits generally increases from south to north. Manganese is a major impurity element in west coast ilmenites. Also, the levels of uranium, thorium, and their radionuclide daughters tend to increase the further north the deposit is located, in association with the increased degree of weathering of the ilmenite.

Numerous companies have been established over the years to recover heavy minerals from these west coast deposits. However, few have been able to ride out the cyclical nature of market conditions (demand and price) and overcome difficult mining and processing conditions.

Commercial production of heavy minerals commenced in 1956 in the Capel region, south of Perth, with the operations of Cable Sands Pty Ltd (Cable Sands) and Western Titanium NL (which became Associated Minerals Consolidated Ltd, and then Renison Goldfields Consolidated Mineral Sands Ltd, RGC). In 1959 Westralian Sands Ltd (Westralian Sands) began mining near Capel. Initial operations in the Capel area generally used dry mining with scrapers and dozers to mine the sand and wet gravity concentration with spirals and cones to produce a heavy mineral concentrate (HMC). Mineral separation was carried out in plants at Capel (RGC), Bunbury (Cable Sands), and in the North Capel and Capel plants of Westralian Sands using spirals, cones, and magnetic and electrostatic separators.

Currently the major operators in Western Australia are Iluka Resources Ltd (Iluka, a merger of Westralian Sands and RGC in 1998) and Tronox Management Pty Ltd (Tronox, formerly TiWest Joint Venture). In April 2019, Tronox acquired Cristal Mining Australia Ltd (Cristal) and with it the Cable Sands operations that Cristal had acquired previously. Tronox has the only integrated operation, with ilmenite from its Cooljarloo mine being fed to its pigment plant at Kwinana. Through the acquisition of Cristal it also has pigment plants near Bunbury. Individual mineral concentrates and upgraded products are exported to overseas customers.

Initially, Western Titanium NL produced a primary ilmenite concentrate (approx. $54 \mathrm{wt} \% \mathrm{TiO}_{2}$ ) as a feedstock for production of titania pigment by the sulphate process. With the supply of rutile ( $>95 \mathrm{wt} \% \mathrm{TiO}_{2}$ ), the preferred feedstock for the chloride process, diminishing, the Becher process was developed by the Western Australian Government Research Laboratory (Becher et al., 1965) to upgrade the primary ilmenite from $54 \mathrm{wt} \% \mathrm{TiO}_{2}$ to a synthetic rutile containing over $90 \mathrm{wt} \% \mathrm{TiO}_{2}$. Large-scale commercial production of synthetic rutile commenced from ' $\mathrm{B}$ plant' at Capel in 1974.

In the Becher process, iron in the ilmenite is reduced at $1100-1180^{\circ} \mathrm{C}$ in a rotary kiln $(5.1 \mathrm{~m}$ diameter and $62 \mathrm{~m}$ in length) for 10 hours to form metallic iron dispersed in a titania 


\section{Technological developments in processing Australian mineral sand deposits}

matrix (reduced ilmenite, $\mathrm{RI}$ ). The locally available reactive Collie coal (and char) is used as the reductant. After magnetic separation to remove residual char, aeration of the reduced ilmenite in an ammonium chloride solution results in oxidation of the metallic iron and precipitation of finely divided iron oxides in the suspension that can be separated easily from the coarser titania grains, typically with a hydrocyclone. The iron oxide is discharged to a storage area from which an iron-rich concentrate is recovered for sale. A leach with dilute sulphuric acid is used to remove residual iron and other impurities from the aeration product to produce a premium-grade synthetic rutile (SR) product containing around $92.5 \mathrm{wt} \% \mathrm{TiO}_{2}$. To increase the reactivity of the primary Capel ilmenite for the Becher process, initially it was necessary to pre-oxidize the mineral at around $1000^{\circ} \mathrm{C}$ in air. When, subsequently, the ilmenite mined at Capel, and from the Eneabba deposits discovered north of Perth in the early 1970s, became progressively more oxidized $\left(58-62 \mathrm{wt} \% \mathrm{TiO}_{2}\right)$, the preoxidation step was no longer necessary.

Work commenced in the late 1960 s at CSIRO, in collaboration with Western Titanium NL, to identify the phase changes occurring in the reduction step of the Becher process in order to optimize the process. Subsequent work targeted the removal of specific impurities by modifications to the Becher processing conditions. To lower the manganese levels, elemental sulphur is added to the reduction kiln to form a manganese sulphide phase (Rolfe, 1973; Li and Merritt, 1990) that dissolves in the acid leach after the aeration step. In another modification, the Synthetic Rutile Enhancement Process (SREP), a borate flux is added during the reduction step to collect uranium and thorium and their radionuclide daughters into an acid-soluble glassy phase that can be leached out after the aeration step to lower uranium and thorium levels in the synthetic rutile to $<100 \mathrm{ppm}$ U+Th (Ellis, Harris, and Hudson, 1994; Aral et al., 1997).

RGC (later Iluka) processed the large Eneabba strandline deposits north of Perth until 2015. Dry and wet mining operations were used, with MSPs at Eneabba and at Narngulu near Geraldton. Two reduction kilns (the $\mathrm{C}$ and $\mathrm{D}$ plants) were commissioned at Narngulu to upgrade ilmenite to synthetic rutile (92-95 wt\% $\mathrm{TiO}_{2}$ ). Over the years Iluka (and its predecessors) processed numerous deposits south of Perth, but in 2018 their operations at the Tutunup South deposit were completed. Production from the Cataby deposit north of Perth commenced in 2019, with an estimated mine life of around 8.5 years. The HMC is separated on site into a nonmagnetic fraction that is transported to the Narngulu MSP for separation of zircon and rutile and a magnetic fraction that is feed for SR production at Capel.

The Tiwest Joint Venture commenced operations at Cooljarloo north of Perth in 1989 using a dredge and floating concentrator to mine and concentrate the heavy minerals. The HMC was transported to a MSP at Chandala. A Becher plant was also built at Chandala to produce SR as a feedstock for the company's chloride pigment plant at Kwinana. Now known as Tronox, the company continues to source its ilmenite from deposits in the Lancelin to Gingin area north of Perth. Image Resources NL recently commenced production of HMC from its Boonanarring deposit near Gingin. The HMC is exported to China for separation.

Several other operations are currently producing ilmenite in the southwest of Western Australia. Tronox (previously Cristal) is producing HMC from its Wonnerup mine, with separation of the minerals at the Cable Sands MSP at Bunbury. The company has five other mines scheduled to come into production and expects to continue mining in the southwest for the next two decades. Doral Mineral Sands Pty Ltd (Doral) is mining deposits in the Jangardup area, also in the southwest of Western Australia, with treatment of the HMC at its MSP at Picton. The current operation is in the western extension to the original project (Burekup), which has a mine life of $3.5-5$ years.

Details of the processing conditions for the major operations in Western Australia have been presented in the Maurice Mawby memorial volumes produced by the Australasian Institute of Mining and Metallurgy (Woodcock, 1980; Woodcock and Hamilton, 1993; Rankin, 2013).

Over the years there have been significant developments in concentration and separation equipment used in the Western Australian operations. More efficient gravity concentration has been achieved with banks of spirals of improved design and materials of construction and improved flow sheets (Palmer and Vadeikis, 2010). Kelsey centrifugal jigs have been used to separate zircon from gangue minerals such as kyanite (Jones and Foster, 2010). The development of higher strength rare earth permanent magnets has resulted in advances in magnetic separators. Several types of rare earth magnetic separators, including rare earth roll (RERMS) and rare earth drum magnetic separators (REDMS) for both wet and dry separations, and matrix-type separators such as wet high-intensity magnetic separators (WHIMS) are used to concentrate and separate heavy minerals in different parts of the processing circuit. Traditional electrostatic separation equipment for nonmagnetic minerals have used combinations of high-tension roll (HTR) and electrostatic plate (ESP) separators. Germain et al. (2003) summarized novel technology that gave better separation efficiency by reducing the effects of particle size. The Julius Kruttschnitt Mineral Research Centre (JKMRC), through the industry-funded Australian Minerals Industry Research Association (AMIRA) P255 project, has developed a range of instruments and process models for improved optimization and control in separation plants (Kojovic, Pax, and Holtham, 1999). Pax (2011) has used finite element modelling of the equipment to improve mineral separation.

Significant developments have also occurred in the characterization of heavy mineral ores, concentrates, and processed products through the commercial availability of instruments such as scanning electron microscopes (SEMs) and electron probe microanalysers (EPMAs) in the 1950s and 1960s. The value of these systems in process mineralogy was quickly established (Jones, 1987; Sutherland and Gottlieb, 1991), although it was not until the late 1990s, when computing hardware and speed were sufficiently advanced, that automated SEMs (Reid et al., 1984; Gu, 2003; Fandrich et al., 2007), and more recently EPMAs (Pownceby and MacRae, 2011, 2016) became commercially available and were routinely applied to mineral sands characterization.

Automated SEM-based systems such as the original QEMSCAN and MLA systems (now owned by Thermo Fisher Scientific) and the more recent TIMA (Tescan), Mineralogic (Carl Zeiss NV), INCAMineral (Oxford Instruments), and AMICS (Hitachi/Bruker) systems have found the greatest use in heavy mineral characterization by providing information such as quantitative modal analysis, mineral grain size, liberation, and textural analysis. The advantage of automated SEMbased mineralogy systems is their ability to rapidly collect quantitative data for many thousands of particle sections, with 


\section{Technological developments in processing Australian mineral sand deposits}

minimal operator intervention (Baum, 2014), and automated mineralogical methods are now widely used in heavy mineral mines and MSPs for ore characterization, grade control, and process design optimization. EPMAs, being of higher cost and usually requiring specialist operators, have largely been limited to generating quantitative chemical information on individual valuable minerals to assess potential marketability and to guide and improve process parameters (e.g. in MSP plants or after upgrading to a high- $\mathrm{TiO}_{2}$ product). More recent EPMA advances have seen the development of integrated $\mathrm{X}$-ray and cathodoluminescence mapping systems (MacRae et al., 2005; Wilson and MacRae, 2005) to illustrate mineral phase distributions (particularly useful for determining particle coatings), impurity mineral/element distributions (Pownceby, 2005; Pownceby, MacRae, and Wilson, 2007), and textural information (Pownceby, 2010), thereby providing a powerful technique for characterizing heavy mineral deposits and process products.

\section{Murray Basin deposits}

Detritus from the weathering and erosion of sediments from the Lachlan fold belt of eastern Australia that was shed to the west was reworked in the palaeo-Darling, Lachlan, Murrumbidgee, and Murray River systems and subsequently deposited in the Murray Basin, the remains of a shallow inland sea (Roy et al., 2000). The basin extends over an area of $320,000 \mathrm{~km}^{2}$ across Victoria, New South Wales and South Australia. In Pliocene times (approx. 5.3-1.8 Ma), economic heavy mineral concentrations formed within the Loxton-Parilla sands unit. These were first reported in the late 1960s and extensive exploration commenced in 1970, leading to the discovery of over a hundred areas of mineralization. However, few of the occurrences contain economic quantities of heavy minerals. Locations of the more important deposits are shown in Figure 2.

The first major discovery in the Murray Basin, in 1982, was the fine-grained WIM 150 deposit near Horsham in the southeast of the basin. Subsequently, four similar deposits (WIM 050, WIM 100, WIM 200, and WIM 250) were discovered nearby. The discovery of the WIM 150 deposit led to increased exploration across the basin and between 1989 and 1999 coarser strandline deposits were discovered and subsequently brought into production. These included Mindarie in the west, Wemen, Kulwin,
Woornack, and Rownack in the centre, Douglas in the south, and Ginkgo and Snapper in the north of the basin (Figure 2).

Murray Basin Titanium Joint Venture (MBTJV) commenced the first operation in the basin at their Wemen deposit in 2001. It was a relatively small resource and mining was completed in 2004. Bemax Resources NL (Bemax) acquired MBTJV, and Cable Sands in Western Australia, in 2004. Iluka commenced their operations in the basin with the Douglas and nearby Echo deposits in 2004, with mining of these two deposits completed in 2012. The Kulwin deposit was mined between 2009 and 2012 and production from the Woornack, Rownack and Pirro (KWP) deposits commenced in 2012 and finished in 2015. Iluka is currently undertaking the development of a large deposit in the Balranald area of New South Wales.

Iluka used wet gravity concentration equipment to produce a HMC. WHIMS was used to separate part of the ilmenite (the most magnetic fraction) which was retained on-site due to its high chromium levels $\left(1-2 \mathrm{wt} \% \mathrm{Cr}_{2} \mathrm{O}_{3}\right)$. The rest of the $\mathrm{HMC}$ was sent to the MSP at Hamilton where zircon, rutile, and weathered ilmenite products were produced. Since completing the treatment of stockpiled HMC, the MSP at Hamilton has closed. Processing conditions used by Iluka are summarized by Hugo and Jones in Rankin (2013).

Bemax commenced production from its Pooncarie deposits in the north of the Murray Basin in New South Wales in 2005. Initial production was from the Ginkgo deposit with the HMC sent to the MSP at Broken Hill that was commissioned in 2006. In 2010 production commenced from the Snapper deposit, and from the nearby Crayfish deposit in 2017. In 2008 Cristal acquired Bemax, and in 2019 Tronox procured Cristal. The HMC produced at the Ginkgo, Snapper, and Crayfish mines is trucked to the recently expanded MSP at Broken Hill, where magnetic leucoxene and secondary ilmenite products are produced and railed to Port Adelaide in South Australia for export. The nonmagnetic fraction is shipped to the Bunbury dry plant for separation of rutile and zircon products that are exported through the port of Bunbury. Little of the ilmenite concentrate was sold initially because of its high chromium content of over $1 \mathrm{wt} \% \mathrm{Cr}_{2} \mathrm{O}_{3}$.

The Mindarie deposit in the west of the basin consists of numerous strandlines between Mindarie and Karoonda in South Australia. Mineralogical data for the deposit reports a grain size of between $45 \mu \mathrm{m}$ and $63 \mu \mathrm{m}$, suggesting that the mineralization

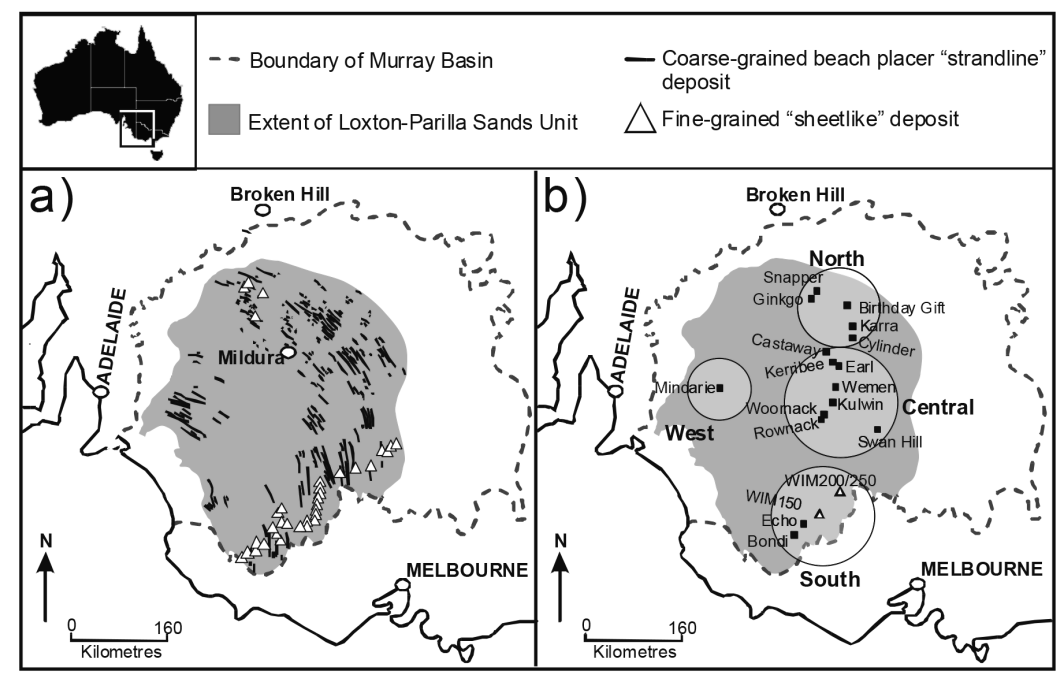

Figure 2-Location map of Murray Basin mineral sand deposits (modified from Pownceby, 2010) 


\section{Technological developments in processing Australian mineral sand deposits}

is finer than that in other strandline deposits in the Murray Basin. The deposit was developed by Australian Zircon NL (Australian Zircon) with production commencing in 2007. The HMC was exported to China. After several changes in ownership, the project was put on care and maintenance in 2015 .

Ilmenite concentrates produced from the Murray Basin deposits contain high levels of chromium due to the presence of chrome spinel minerals. The wide range in the composition of these spinels makes it hard to remove them during processing. Extensive experimental work has been done to characterize the compositional variations (Pownceby, 2010), and Bruckard et al. (2015) summarized the various treatment conditions evaluated to remove the chrome spinels to obtain products with chromium levels low enough for pigment production. A magnetizing roast to increase the magnetic susceptibility of the titanate grains relative to that of the chrome spinels has been shown to yield a titanate product with a lower chromia content after magnetic separation. For a primary ilmenite fraction, a low-temperature magnetizing roast around $600^{\circ} \mathrm{C}$, which limits the amount of rutile produced in the roast, is successful. (Rutile does not dissolve well in concentrated sulphuric acid.) A higher roasting temperature may be used with weathered ilmenite since the formation of rutile during the roast is not a problem in the subsequent chlorination process. Bemax has proposed constructing a multi-hearth fluid bed roaster at its Broken Hill MSP to roast high-chromium ilmenite at around $620^{\circ} \mathrm{C}$ under reducing conditions to yield a magnetic product suitable as a chlorinatable feedstock in which the chromium content has been lowered from $>1.5 \mathrm{wt} \%$ to $<0.3 \mathrm{wt} \% \mathrm{Cr}_{2} \mathrm{O}_{3}$ (Everett et al., 2003).

Under reducing conditions, such as in a Becher reduction kiln, chromium is chalcophilic and has a strong affinity for sulphur. The possibility of modifying the chemical and physical properties of the chrome spinels in a Murray Basin ilmenite concentrate was investigated by adding elemental sulphur to the Becher reduction step. Examination of the reduced ilmenite product revealed the presence of small amounts of bronze-coloured grains indicating chrome spinels coated with rims of sulphur-rich phases (i.e., selective chromite sulphidization). After de-metallization of the reduced ilmenite, removal of the sulphur-coated chrome spinel grains may be possible by flotation using reagents typically used to float base metal sulphides. Initial results were promising, and further work is in progress to optimize the treatment conditions (Ahmad et al., 2014, 2016; Rhamdhani et al., 2018). In Western Australian Becher plants, chromite is removed in the nonmagnetic fraction from the magnetic separation after reduction of the ilmenite.

Weathered ilmenites are usually upgraded to over $90 \mathrm{wt} \%$ $\mathrm{TiO}_{2}$ to serve as feedstock for a chloride pigment plant. Processes that may be used for Murray Basin weathered ilmenites include kiln-based or fluidized bed processes. Magnesium and manganese are major impurities in Murray Basin ilmenites, and while manganese levels can be lowered by addition of elemental sulphur in the reduction step of the Becher process, magnesium is not removed in a standard Becher treatment. Consequently, modifications to the Becher processing conditions have been proposed to produce satisfactory sulphate and chloride pigment feedstocks from weathered Murray Basin ilmenites. Kiln-based processes that have been evaluated for Murray Basin weathered ilmenite concentrates include the Hybrid, Acid Soluble Synthetic Rutile (ASSR) and the Recovery of Upgraded Titania by Impurity Liquefaction and Extraction (RUTILE) processes. While these processes have been tested at pilot plant scale, the use of a modified Becher process is likely to require demonstration of the technology at a larger scale. The Murso, Austpac ERMS and NewGenSR processes use fluidized bed reactors to oxidize and reduce iron in the ilmenite at temperatures between 750 and $1000^{\circ} \mathrm{C}$. All these processes have been demonstrated at pilot plant scale, but no commercial operation has been established as yet. A summary of the application of these processes to weathered Murray Basin ilmenites has been given by Bruckard et al. (2015).

\section{Eucla Basin deposits}

Another major heavy mineral province in Australia is the Eucla Basin, an approximately $2000 \mathrm{~km}$ wide marginal marine basin spanning the border between South Australia and Western Australia (Hou, Keeling, and Hocking, 2011). Exploration since 2004 has led to the discovery of numerous major heavymineral deposits in Tertiary shorelines along the east of the basin (Jacinth, Ambrosia, Atacama, Typhoon, and Cyclone). Other prospects (Cyclone Extended, Balladonia, and Plumridge) are around the western edge of the basin (Hou, Keeling, and Hocking, 2011; Pownceby, Sparrow, and Fisher-White, 2008). Iluka commenced production from the Jacinth deposit in October 2009 , primarily for production of zircon. After a short suspension in production in April 2016, production recommenced in December 2017 with the HMC being transported to the Narngulu MSP in Western Australia. Mining of the Ambrosia deposit is expected to commence in 2019. At Narngulu, a hot acid leach is used to clean the surfaces of the final zircon product to lower iron contamination levels.

\section{Future developments}

\section{New deposits}

In addition to the commercial operations noted above, several companies are actively evaluating other resources in Western Australia. Sheffield Resources Limited is evaluating several prospects in the Eneabba area. North of Geraldton, Strandline Resources Limited has the Coburn heavy mineral sands project just south of Shark Bay, and even further north is the flagship Thunderbird mineral sands deposit of Sheffield Resources Limited. This project is in the Canning Basin, on the Dampier Peninsula west of Derby, and is the first major mineral sand deposit discovered in the Canning Basin. A prefeasibility study indicated that an ilmenite product with $56.1 \% \mathrm{TiO}_{2}$ and low levels of alkalis and chromium could be produced from the deposit following a low-temperature roast.

In Victoria, future developments are expected to occur in the north of the Murray Basin. Iluka is developing a large deposit in the Balranald area. This deposit is under $60 \mathrm{~m}$ of overburden and underground mining and backfilling techniques are being evaluated to recover the heavy minerals. Cristal Mining is developing the Atlas/Campaspe Project north of Balranald with a planned mine life of 11-20 years.

Also in Victoria, there are many occurrences of mineral sands around the eastern edge of the Murray Basin. Over the years numerous companies have evaluated them but no development has occurred. The Gippsland Basin in the southern part of Victoria also is host to extensive late Miocene-Pliocene strandline deposits and exploration and drilling have shown that these have similar properties to the Murray Basin strandline deposits. The Glenaladale deposit was discovered by Rio Tinto Exploration in 2004, and in 2013, Kalbar Resources Ltd (Kalbar) acquired the 


\section{Technological developments in processing Australian mineral sand deposits}

resource and has started developing the higher grade areas as its Fingerboards Mineral Sands Project.

\section{Developments for fine-grained mineralization}

The five WIM-type deposits located in the south of the Murray Basin around Horsham are fine-grained, sheet-like heavy mineral deposits. The WIM 150 deposit was discovered by CRA Limited, now Rio Tinto Pty Ltd, with initial development carried out through its subsidiary company, Wimmera Industrial Minerals Pty Ltd (WIM). An intensive effort was made to develop processing options for the WIM 150 deposit, including pilot plant test work, but no commercial operation resulted and WIM relinquished its leases on the deposits. They were subsequently taken up by other companies (e.g., Australian Zircon and Murray Zircon - now a joint venture between OZC and Million Up Ltd) but despite a significant amount of further development work the deposits still have not come into production.

Astron Ltd (Astron) is evaluating two WIM-type deposits; WIM 200 (the Jackson deposit) and WIM 250 (the Donald deposit). Astron is concentrating on production from the Donald deposit first, and proposes to produce a HMC for export to China for further processing.

While the extensive WIM-type deposits located in the south of the Murray Basin contain more heavy minerals than there are in the strandline deposits in the basin, they remain undeveloped. Although they are low grade, the fine particle size has been the major issue preventing them from being developed to date. A significant amount of research has been undertaken to design equipment and identify processing options to concentrate and separate these fine minerals.

Continuing developments are being made with the design of spirals to increase the recovery of the finer mineralization from the WIM-type deposits (Richards et al., 2000). Higher mineral recoveries of fines down to around $6 \mu \mathrm{m}$, with better concentrate grades, and separation of minerals with small specific gravity differences are claimed with a Kelsey jig compared with other gravity separation techniques (Jones and Foster, 2010). Kelsey jigs, along with spirals and flotation, are proposed to be used in processing the WIM 150 deposit. Capps and Waldram (1986) have reported the recovery of fine-grained (32-75 $\mu \mathrm{m})$ heavy minerals from a mineral sand deposit using Kelsey jigs. Wet magnetic separators are usually considered to be efficient for minerals with particle sizes above $75 \mu \mathrm{m}$. Consequently, it is likely that magnetic separation efficiencies for fine-grained deposits may not be satisfactory.

Flotation has been used to concentrate and separate heavy minerals, and since it operates efficiently with fine $(<100 \mu \mathrm{m})$ particle sizes, it can be expected to be applicable to the concentration and separation of heavy minerals in the finegrained deposits (Bruckard et al., 1999). A strategy of producing a bulk float of the valuable minerals, depression of the titanium minerals, and a float to separate the rutile and ilmenite using modern collectors (e.g., sulphosuccinamates, phosphonic acids, amines) is expected to be able to yield individual concentrates of the fine-grained minerals. Pownceby et al. (2015) have summarized some of the reported flotation work with WIM 150 samples.

Removal of chrome spinels from the ilmenite concentrate will also be an issue with the fine-grained deposits. Flotation and roasting conditions discussed above for the coarser-grain deposits should also be applicable to the finer mineralization. However, there are expected to be problems in treating the fine- grained mineralization with a fluidized bed or kiln-based process as the particles may be blown out of the fluidized bed, or from a rotary kiln in the high exhaust gas flows from the kiln. Research is required to design a circulating fluidized bed reactor capable of treating fine-grained mineralization, or to determine whether agglomeration of fine-grained ilmenite can successfully be used in existing reactor designs.

The final zircon concentrate, as well as requiring attritioning in water and acid or alkaline solutions to remove surface contaminants, is also likely to require further treatment to lower radionuclide (uranium, thorium, and their daughter products) levels in the grains. Heat and leach treatments that involve decomposition of zircon either through the addition of a flux, or through the application of temperatures above the temperature at which zircon breaks down to zirconia and quartz, and other fluxbased treatments that retain the integrity of the zircon crystalline lattice have been used to significantly lower the U+Th levels in the fine-grained zircon. Pownceby et al. (2015) have summarized this work.

\section{Summary}

Australia has four major mineral sands provinces. Since 1934, when the commercial mining of mineral sands commenced in eastern Australia, there has been continuous mining and processing of heavy minerals from these deposits. This has been associated with significant advances in equipment design to recover the heavy minerals and in processing conditions to remove impurity elements from the heavy minerals to produce marketable products for further local processing or for export. New deposits currently being characterized and developed will ensure continuing production of heavy minerals in Australia.

\section{Acknowledgements}

Some information and details of current operations were taken from company web sites. Alex de Andrade is acknowledged for information on recent developments in separation equipment by Minerals Technologies. The external reviewers are thanked for their valuable comments.

\section{References}

Ahmad, S., Rhamdhani, M.A., Pownceby, M.I., and Bruckard, W.J. 2014. Thermodynamic assessment and experimental study of sulphidation of ilmenite and chromite. Transactions of the Institution of Mining and Metallurgy C: Mineral Processing and Extractive Metallurgy, vol. 123, no. 3. pp. 165-177.

Ahmad, S., Rhamdhani, M.A., Pownceby, M.I., and Bruckard, W.J. 2016. Selective sulphidising roasting for the removal of chrome spinel impurities from weathered ilmenite ore. International Journal of Mineral Processing, vol. 146. pp. 29-37.

Aral, H., Bruckard, W.J., Freeman, D.E., Grey, I.E., Harris, H.R., Houchin, M.R., McDonald, K.J., and Sparrow, G.J. 1997. Radionuclide removal from Eneabba North ilmenite. Proceedings of Heavy Minerals 1997. Robinson R.E. (ed.). South African Institute of Mining and Metallurgy, Johannesburg. pp. 137-142.

BAUM, W. 2014. Ore characterization, process mineralogy and lab automation a roadmap for future mining. Minerals Engineering, vol. 60. pp. 69-73.

Becher, R.G., CAnning, R.G., Goodheart, B.A., and Uusna, S. 1965. A new process for upgrading ilmenitic mineral sands. Proceedings of the Australasian Institute of Mining and Metallurgy, no. 214, June. pp. 21-43.

Bramdeo, S. and Dunlevey, J.N. 1999. Mineral chemistry of rutile. Proceedings of Heavy Minerals 1999. Stimson R.G. (ed.). South African Institute of Mining and Metallurgy, Johannesburg. pp. 63-65.

Britt, A., Senior, A., Summerfield, D., Hughes, A., Hitchman, A., Champion, D., Huston, D., Simpson, R., Kay, P., Sexton, M., and Schofield, A. 2019. Australia's identified mineral resources 2018, Geoscience Australia, Canberra. doi: http://dx.doi. org/10.11636/1327-1466.2018 [accessed 19 March 2019]. 


\section{Technological developments in processing Australian mineral sand deposits}

Bruckard, W.J., Creed, M.D., Guy, P.J., and Heyes, G.W. 1999. Beneficiation of Australian mineral sands deposits using flotation. Extended abstracts: Murray Basin Mineral Sands Conference. Stewart, R. (ed.). Australian Institute of Geoscientists Bulletin, no. 26. pp 111-115.

Bruckard, W.J., Pownceby, M.I., Smith, L.K., and Sparrow, G.J. 2015. Review of processing conditions for Murray Basin ilmenite concentrates. Transactions of the Institution. of Mining. and Metallurgy C: Mineral Processing and Extractive Metallurgy, vol. 124, no. 1. pp. 47-63.

CAPPS, P.G. and WALDRAM, J.T. 1986. Concentration of fine grained heavy minerals using the Kelsey centrifugal jig. Proceedings of Australia: A World Source of Ilmenite, Rutile, Monazite and Zircon. Australasian Institute of Mining and Metallurgy, Melbourne. pp. 99-106.

EluIs, B.A., Harris, H.R., and Hudson, R.L. 1994. The reduction of radionuclides in titaniferous feedstocks. Proceedings of the 11th Industrial Minerals International Congress. Griffiths J.B. (ed.). Industrial Minerals Division of Metal Bulletin plc, Surrey, UK. pp. 102-108.

Everett, S.C., Schache, I.S., Balderson, G.F., and Bannister, P.A. 2003. Pooncarie Project - The technical challenges. Proceedings of Heavy Minerals 2003. South African Institute of Mining and Metallurgy, Johannesburg. pp. 81-93.

Fandrich, R., Gu, Y., Burrows, D., and Moeller, K. 2007. Modern SEM-based mineral liberation analysis. International Journal of Mineral Processing, vol. 84. pp. 310-320.

Germain, M., Lawson, T., Henderson, D.K., and MacHunter, D.M. 2003. The application of new design concepts in high tension electrostatic separation to the processing of mineral sands concentrates. Proceedings of Heavy Minerals 2003. South African Institute of Mining and Metallurgy, Johannesburg. pp. 101-107.

GREy, I.E. and REID, A.F. 1975. The structure of pseudorutile and its role in the natural alteration of ilmenite. American Mineralogist, vol. 60. pp. 898-906.

GREY, I.E. and LI, C. 2003. Hydroxylian pseudorutile derived from picroilmenite in the Murray Basin, southeastern Australia. Mineralogical Magazine, vol. 67, no. 4. pp. 733-747.

Grey, I.E., Steinike, K., and MacRae, C.M. 2013. Kleberite, $\mathrm{Fe}^{3+} \mathrm{Ti}_{6} \mathrm{O}_{11}(\mathrm{OH})_{5}$, a new ilmenite alteration product, from Königshain, northeast Germany. Mineralogical Magazine, vol. 77, no. 1. pp. 45-55

Gu, Y. 2003. Automated scanning electron microscopy based mineral liberation analysis. An introduction to JKMRC/FEI Mineral Liberation Analyser. Journal of Minerals and Materials Characterization and Engineering, vol. 2. pp. 33-41.

Hou, B., KeELing, J.L., and Hocking, R.M. 2011. Heavy mineral prospectivity in the Eucla Basin. Proceedings of Eighth International Heavy Minerals Conference. Australasian Institute of Mining and Metallurgy, Melbourne. pp. 135-145.

JonEs, M.P. 1987. Applied Mineralogy: A Quantitative Approach. Graham and Trotman, London.

Jones, T. and Foster, A. 2010. Smarter gravity separation using the Kelsey centrifugal jig. Proceedings of the XXV International Mineral Processing Congress (IMPC) 2010. Australasian Institute of Mining and Metallurgy, Melbourne. pp. $859-869$

Kojovic, T., Pax, R., and Holtham, P. 1999. Developments in titanium minerals processing technology. Extended abstracts: Murray Basin Mineral Sands Conference. Stewart, R. (ed.). Australian Institute of Geoscientists. Bulletin No. 26. pp 139-144.

Li, C. and MerRITT, R.R. 1990. Reduction of ilmenite in the presence of sulphur. Australian Journal of Chemistry, vol. 43, no. 1. pp. 1-9.

MacRae, C.M., Wilson, N.C., Johnson, S.A., Philuips, P.L., and Otsuki, M. 2005. Hyperspectral mapping - combining cathodoluminescence and X-ray collection in an electron microprobe. Microscopy Research and Technique, vol. 67. pp. 271-277.

MoRLey, I.W. 1981. Black Sands. A History of the Mineral Sand Mining Industry in Eastern Australia. University of Queensland Press, St Lucia. 278 pp.

Palmer, M. and VadeiKis, C. 2010. New developments in spirals and spiral plant operations. Proceedings of the XXV International Mineral Processing Congress (IMPC) 2010. Australasian Institute of Mining and Metallurgy, Melbourne. pp. 1099-1108.

PAx, R.A. 2011. The use of finite element modelling to better understand electrostatic separation. Proceedings of the Eighth International Heavy Minerals
Conference. Australasian Institute of Mining and Metallurgy, Melbourne. pp. 239-249.

Popp, A.W. 2005. Murray Basin heavy mineral strandline deposit mineralogy. Proceedings of Heavy Minerals 2005. Asker M. and Elder J. (eds). Society for Mining, Metallurgy and Exploration, Inc., Littleton, CO. pp. 91-102.

PownceBY, M.I. 2005. Compositional and textural variation in detrital chrome spinels from the Murray Basin, southeastern Australia. Mineralogical Magazine, vol. 69. pp. 191-204.

PownceBy, M.I. 2010. Alteration and associated impurity element enrichment in detrital ilmenites from the Murray Basin, southeast Australia: a product of multistage alternation. Australian Journal of Earth Science, vol. 57. pp. 243-258.

Pownceby, M.I., Sparrow, G.J., and Fisher-White, M.J. 2008. Characterisation of ilmenites from western Eucla Basin heavy mineral concentrates. Proceedings of the Ninth International Congress for Applied Mineralogy. Australasian Institute of Mining and Metallurgy, Melbourne. pp. 537-544.

PownceBY, M.I. and MAcRAE, C.M. 2011. Electron beam analysis techniques used for the characterization of industrial minerals. Advances in the Characterization of Industrial Minerals, Christidis, G. (ed.). EMU Notes in Mineralogy, 9. European Mineralogical Union and the Mineralogical Society of Great Britain \& Ireland. pp. 227-286.

Pownceby, M.I. and MacRAE, C.M. 2016. Electron probe microanalyser. ProcesS Mineralogy. Becker, M., Wightman, E.M. and Evans, C.L. (eds.). Julius Kruttschnitt Mineral Research Centre, University of Queensland, Indooroopilly. pp. 79-96.

PownceBy, M.I., MAcRAE, C.M., and WILSON, N.C. 2007. Mineral characterisation by EPMA mapping. Minerals Engineering, vol. 20. pp. 444-451.

Pownceby, M.I., Sparrow, G.J., Aral, H., Smith, L.K., and Bruckard, W.J. 2015. Recovery and processing of zircon from Murray Basin mineral sand deposits. Transactions of the Institution. of Mining. and Metallurgy C: Mineral Processing and Extractive Metallurgy, vol. 124, no. 4. pp. 240-253.

RAnKin, W.J. (ed.). 2013. Mineral Sands. Australasian Mining and Metallurgical Operating Practices. The Maurice Mawby Memorial Volume. 3rd edn. Australasian Institute of Mining and Metallurgy, Melbourne. vol. 2. pp. 1683-1718.

Reid, A.F., Gottlieb, P., MacDonald, K.J., and Miller, P.R. 1984. QEM*SEM® image analysis of ore minerals: volume fraction, liberation and observational variances. Applied Mineralogy. Park, W.C. Hansen, D.M. and Hagni, R.D. (eds). AIME, New York, NY. pp. 191-204.

Rhamdhani, M.A., Ahmad, S., Pownceby, M.I., Bruckard, W.J., and Harjanto, S. 2018. Selective sulphidation of impurities in weathered ilmenite. Part 1 - Applicability to different ilmenite deposits and simulated Becher kiln conditions. Minerals Engineering, vol. 121. pp. 55-65.

Richards, R.G., MacHunter, D.M., Gates, P.J., and Palmer, M.K. 2000. Gravity separation of ultra-fine $(-0.1 \mathrm{~mm})$ minerals using spiral separators. Minerals Engineering, vol. 13, pp. 65-77.

RoLfE, P.E. 1973. The modified metallurgical upgrading of ilmenite to produce high grade synthetic rutile. Proceedings of the AusIMM Conference Series No. 2, Perth, May 1973. Australasian Institute of Mining and Metallurgy, Melbourne. pp. 443-453.

Roy, P.S., Whitehouse, J., Cowell, P.J., and OAKES, G. 2000. Mineral sands occurrences in the Murray Basin, southeastern Australia. Economic Geology, vol. 95. pp. 1107-1128.

SinHA, H.N. 1973. The Murso process for producing rutile substitute. Titanium Science and Technology. Jaffee, R.I. and Burte H.M. (eds.). Plenum Press, New York - London. pp. 233-245.

SutherLAND, D. and GoTTLIEB, P. 1991. Application of automated quantitative mineralogy in mineral processing. Minerals Engineering, vol. 4. pp. 753-762.

WILSON, N.C. AND MAcRAE, C.M. 2005. An automated hybrid clustering technique applied to spectral data set. Microscopy and Microanalysis, vol. 11, supplement 2, 434CD.

Woodсоск, J.T. (ed.). 1980. Mineral sands. Mining and Metallurgical Practices in Australasia. The Maurice Mawby Memorial Volume. Australasian Institute of Mining and Metallurgy, Melbourne. pp. 733-789.

Wooрсоск, J.T. and HаміLтоN, J.K. (eds). 1993. Mineral Sands. Australasian Mining and Metallurgy,. The Maurice Mawby Memorial Volume. 2nd edn. Australasian Institute of Mining and Metallurgy, Melbourne. vol. 2. pp. 1250-1328. 